\title{
Adel T. Adamova, Manijeh Bayani. Persian Painting. The Arts of the Book and Portraiture. The al-Sabah Collection
}

Alexandra Van Puyvelde

\section{(2) OpenEdition Journals}

Electronic version

URL: http://journals.openedition.org/abstractairanica/42710

DOI: 10.4000/abstractairanica.42710

ISBN: 1961-960X

ISSN: 1961-960X

Publisher:

CNRS (UMR 7528 Mondes iraniens et indiens), Éditions de l'IFRI

\section{Electronic reference}

Alexandra Van Puyvelde, « Adel T. Adamova, Manijeh Bayani. Persian Painting. The Arts of the Book and Portraiture. The al-Sabah Collection », Abstracta Iranica [Online], Volume 37-38-39 | 2018, document 6, Online since 10 March 2018, connection on 26 September 2020. URL : http:// journals.openedition.org/abstractairanica/42710; DOI : https://doi.org/10.4000/abstractairanica 42710

This text was automatically generated on 26 September 2020 .

Tous droits réservés 


\title{
Adel T. Adamova, Manijeh Bayani. Persian Painting. The Arts of the Book and Portraiture. The al-Sabah Collection
}

\author{
Alexandra Van Puyvelde
}

\section{REFERENCES}

Adel T. Adamova, Manijeh Bayani. Persian Painting. The Arts of the Book and Portraiture. The al-Sabah Collection, Kuwait, London, Thames \& Hudson, 2015, 552p., ill., bibliography, indices, table of concordance.

1 This publication is a new volume in a series, presenting the famous al-Sabah Collection in Kuwait. The authors wrote thorough entries on 41 exquisite examples of Persian book art and painting, which they situate in their art-historical context.

2 The publication is written for both the general audience and specialists, a difficult task in which the authors have been very successful. Each chapter starts with a short and easy reading historical and art-historical introduction, so that the non-specialized reader can be familiarized with the production of the period and the kind of work that will be discussed in the entries. The entries are conceived as essays, presented in chronological order. On the one hand, they contain general information about the content of the manuscript or subject of the painting, about its author (if known) and its art-historical significance. On the other hand, they include detailed descriptions, information about the history of the work, a brief codicological description, discussions about attributions and the iconography and stylistic and iconographic comparisons with other works of art. At the end of the volume, the colophons, seal impressions, library notes and notes of later owners are presented as they appear in Persian and Arabic in the manuscripts. Particular attention is paid to the issue of the so called 
"commercial" style, which flourished in the $15^{\text {th }}$ and $16^{\text {th }}$ centuries in Shiraz and which is represented in several examples in the al-Sabah collection.

3 All entries are abundantly accompanied by good images. With the exception of the two copies of al-Qazwini's 'Aja'ib al-makhluqat, the illustrations of each manuscript are published in their entirety and separate folios are reproduced on both sides.

4 Some works especially drew attention. There are of course the rare pre-Mongol manuscripts, folios and a drawing, dating to the $11^{\text {th }}, 12^{\text {th }}$ and early $13^{\text {th }}$ century. An important manuscript of the Arabic lexical work Kitab al-Sihah fi'l-lughah ("The Book of Linguistic Accuracy") by Isma'il ibn Hammad al-Jawhari, is copied and signed in Shiraz, dated in 1342 and dedicated to the Inju ruler Shaykh Abu Ishaq. This is the first known manuscript with a dedication to this ruler, who was a lover of art and literature and whose name figures also on some metalwork objects, kept in different museums. Another interesting (incomplete) manuscript, already known by scholars, is an autographed and dated anthology of poetry by Muhammad ibn Badr al-Din al-Jajarmi. This manuscript too might have been dedicated to Abu Ishaq and there are serious indications that it was copied and illustrated in Isfahan, a previously unknown centre for the production of manuscripts in the $14^{\text {th }}$ century. A still life by Bahram SofrahKash, dated 1640-41, showing European and Indian influences and reminding Flemish and Dutch still lives with flower bouquets, invites for further study.

\section{AUTHORS}

\section{ALEXANDRA VAN PUYVELDE}

Royal Museums of Art \& History, Bruxelles 